\title{
Depositional Environments and Geochemical Assessments of the Bende Ameki Formation Potential as Petroleum Source Rocks in the Ogbunike Quarry, South-Eastern Nigeria
}

\author{
Olajubaje, T. A., \\ Akande, S. $\mathrm{O}$., \\ Department of Geology and Mineral Sciences, \\ University of Ilorin, Ilorin, Nigeria \\ Adeoye, J. A., \\ Department of Geosciences, Mountain Top University, Ibafo, Nigeria \\ Adekeye, $O$. A., \\ Department of Geology and Mineral Sciences, \\ University of Ilorin, Ilorin, Nigeria \\ Friedrich, $\boldsymbol{C}$. \\ West Sam Houston Parkway North, Houston TX, USA
}

Doi: 10.19044/esj.2018.v14n27p157 URL:http://dx.doi.org/10.19044/esj.2018.v14n27p157

\begin{abstract}
This paper focuses on investigating the paleoenvironments and hydrocarbon generation potentials of the outcropping Eocene Bende-Ameki Formation at Ogbunike quarry, Anambra Basin southeastern Nigeria, which is the Niger Delta Agbada Formation subsurface equivalent. The fine to coarse sandstones interbedded with parallel laminated grey, coaly shales, and bioturbated claystones were the dominant rock facies. The shales contain Ammobaculities, Ammontium, lenticulina, and Reophax benthic foraminifera of brackish to outer shelf environments. The rock sequence and biofacies associations indicate a fluvial, shoreface to delta environments. The marine and continental paleoenvironments are supported by the concentration and association of redox-sensitive trace elements such as vanadium and nickel of oxic to dysoxic paleoconditions. The twenty shales have a range of TOC from $0.39-8.81 \mathrm{wt} \%$ (mean $2.22 \mathrm{wt} \%$ ), suggesting a good to very good source rocks. The organic richness is highest within the depth of $2-6 \mathrm{~m}$ across the quarry. Their genetic potential $\left(\mathrm{S}_{1}+\mathrm{S}_{2}\right)$ ranges from $0.22-27.35$ (mean 2.8 $\mathrm{kgHC} /$ ton) of rock, and hydrogen index from 26 to $292 \mathrm{mgHC} / \mathrm{gTOC}$ with a mean of $67.3 \mathrm{mgHC} / \mathrm{gTOC}$. This, however, indicates dominance of Type III gas prone kerogen of terrestrial origin. The oxygenated water column
\end{abstract}


characterized by the presence of benthonic scavengers may not preserve lipidenriched organic constituents of anoxic paleoenvironments which could account for the rare Type II oil and gas prone kerogen in the source rock. The thermal history inferred from the Tmax between $401{ }^{\circ} \mathrm{C}-424^{\circ} \mathrm{C}$ suggests that the source rocks are immature at the present stratigraphic level.

Keywords: Ogbunike, Anambra Basin, Eocene, Bende-Ameki, Source rock, Paleoenvironments

\section{Introduction}

The $40,000 \mathrm{~km}^{2}$ Anambra Basin in the southeastern Nigeria is bounded to the south by the Niger Delta hinge line and northwesterly by the Benue basins and Abakaliki fold belt to the southeast (Figure 1). It consists of about 6,000 m thick Cretaceous to Tertiary sedimentary rocks. It has been explored as far back as the early 60 's with many exploratory wells drilled with some success. Neogene stratigraphic units are consequent to short periods of transgression and long period of regression responsible for cyclic pattern of the shales and sandstone facies which are traceable to the subsurface Niger Delta. The present study investigated the exposed Miocene shales beds located on the coordinate of $6^{\circ} 10^{\prime} 48^{\prime \prime} \mathrm{N}$ and $6^{\circ} 51^{\prime} 50^{\prime \prime} \mathrm{E}$ at Ogbunike quarry, Anambra State southeastern Nigeria (Figure 2). The study seeks to report the paleoenvironments of the shale facies and its impact on their organic matter quality and quantity for hydrocarbon generation for the first time.

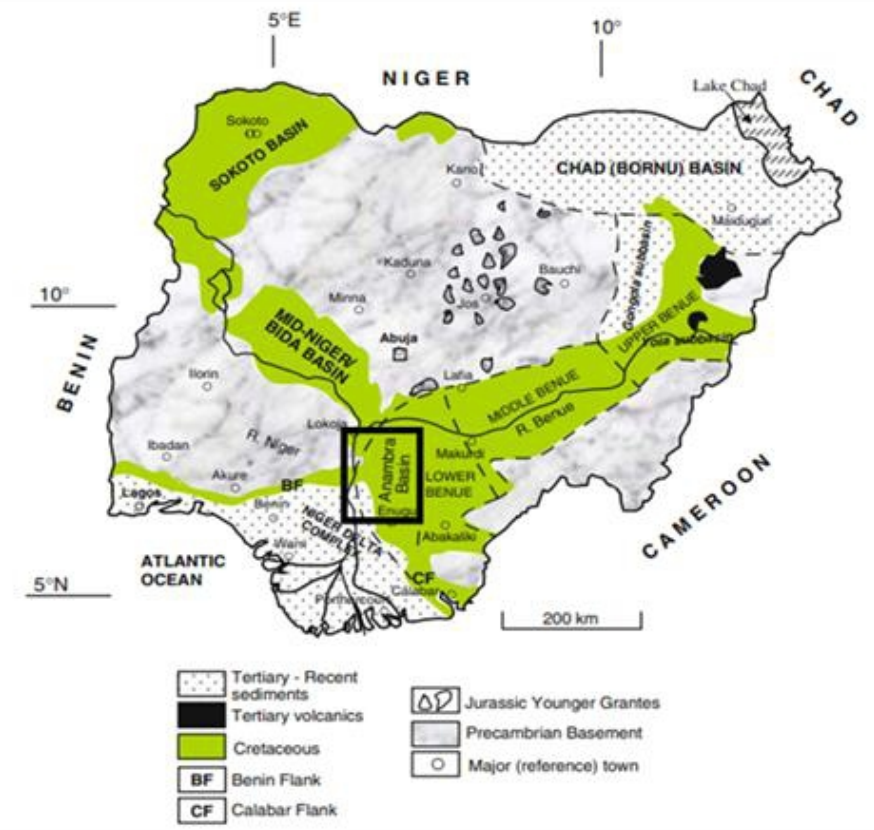

Figure 1. Generalized geological map of Nigeria showing the Anambra Basin in the thick rectangular box (modified after Obaje, 2004). 


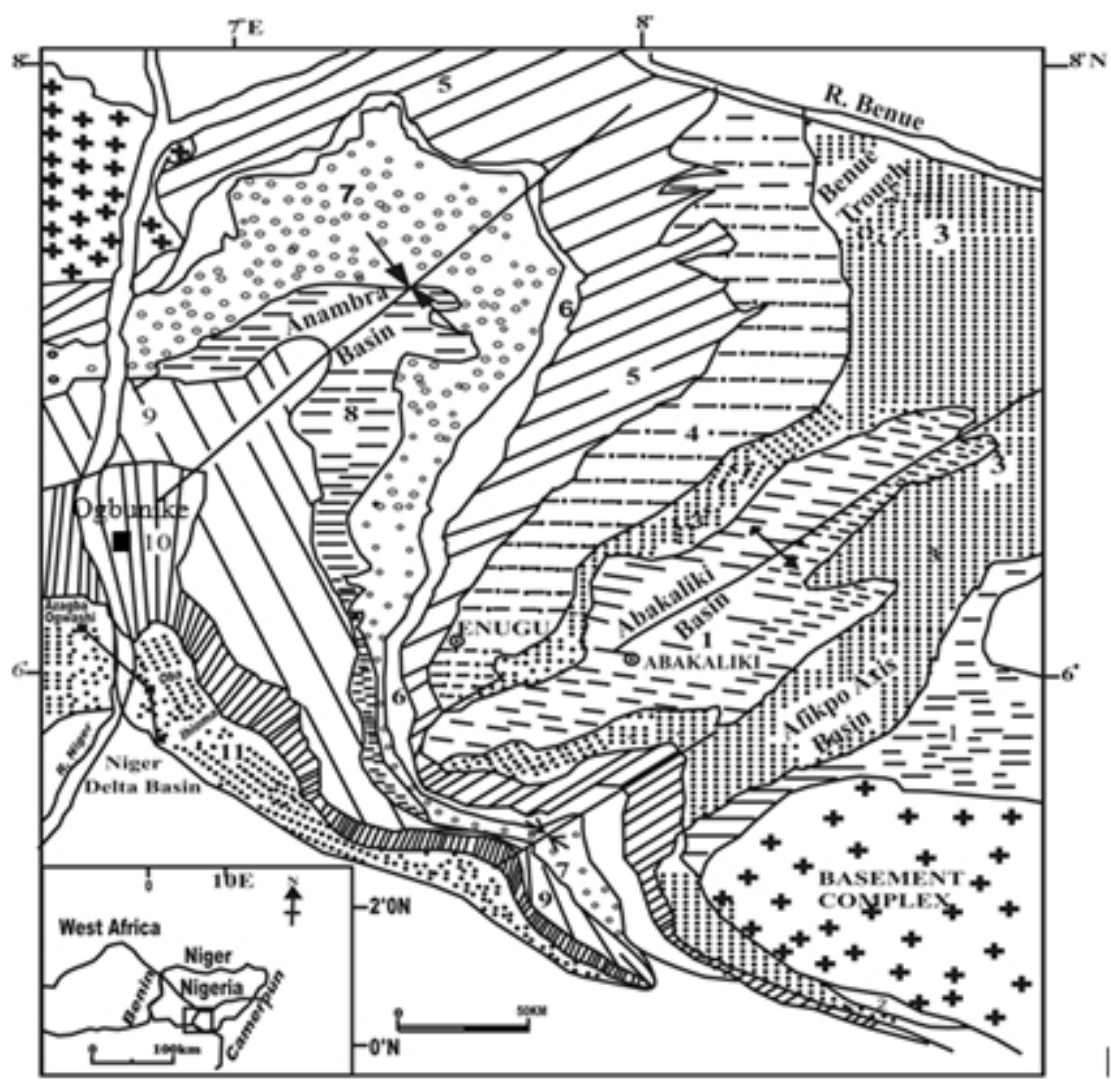

Figure 2. Generalized geological map of southern Benue Trough, Nigeria, showing the location of Ogbunike Quarry in black box (Modified after Akande et al., 2010)

\section{Geology and Stratigraphy of Anambra Basin}

The Benue Trough has been described as the failed arm among the successfully rifted areas of Gulf of Guinea and South Atlantic Ocean of the triple arm junction, along which spreading resulted in the Africa plate separating from the South America plate (Olade, 1975). The trough was stretched in a NE-SW direction resting unconformably upon the Precambrian crystalline basement. It is then geographically divided into northern, central, and southern Benue Trough. Southern Benue Trough consists of the oldest sediments of mid to late Cretaceous in Abakaliki Basin and post-Santonian to Neogene sediment in the Anambra Basin. The Abakaliki Basin's platform (Figure 2) was subsided during the Santonian tectonic events in the eastern part of the trough, displacing the depocentre to the west and northwest to form Anambra basin which received large volume of siliciclastic sediments (Murat, 1972). The resulting rock succession comprises of the Nkporo Group, Mamu Formation, Ajali Sandstone, Nsukka Formation, Imo Formation, and the Ameki Group (Figure 3). The third sedimentary phase, which initiated the 
formation of the petroliferous Niger Delta, commenced in the late Eocene as a result of a major earth movement that further structurally inverted the Abakaliki region and displaced the depositional axis further to the south of the Anambra Basin (Obi et al., 2001).

\begin{tabular}{|c|c|c|}
\hline $\begin{array}{c}\text { AGE } \\
\text { (Not to Scale) }\end{array}$ & $\frac{\sqrt{3}}{\sqrt[3]{2}}$ & FORMATION \\
\hline $\begin{array}{l}\text { QUATERNARY } \\
\text { PLIOCENE }\end{array}$ & & BENIN FORMATION \\
\hline $\begin{array}{l}\text { MIOCENE } \\
\text { OLIGOCENE }\end{array}$ & & OGWASHI ASABA FORMATION \\
\hline EOCENE & & $\begin{array}{l}\text { BENDE } \\
\text { AMEKI } \\
\end{array}$ \\
\hline PALEOCENE & 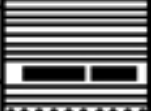 & $\begin{array}{l}\text { IMO SHALE } \\
\text { NSUKKA FORMATION }\end{array}$ \\
\hline MAASTRICHTIAN & 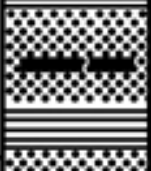 & $\begin{array}{l}\text { AJALI } \\
\text { MAMU SANDSTONE } \\
\text { ASATA }-N \text { EORMATION }\end{array}$ \\
\hline CAMPANIAN & & \\
\hline SANTONIAN & & \\
\hline CONIACIAN & & ALE \\
\hline TURONIAN & & 空 \\
\hline CENOMANIAN & & \\
\hline ALBIAN & $\because$ & $\begin{array}{l}\text { AWE FORMATION } \\
\text { ABAKALIKI SHALE } \\
\text { AWI FORMATION }\end{array}$ \\
\hline 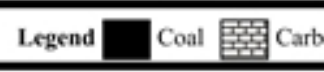 & S & 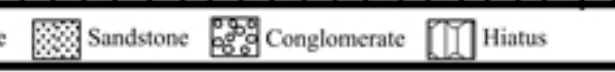 \\
\hline
\end{tabular}

Figure 3. Stratigraphic and lithologic section of Lower Benue Trough and Anambra Basin (Modified after Akaegbobi et al., 2000) 


\section{Nkporo Formation (Campanian - Maastrichtian)}

Nkporo Formation consists of a sequence of bluish to dark grey shale and mudstone which is locally with sandy shales, thin sandstones, and shelly limestone beds. The shaly facies grade laterally to sandstones of the Owelli and Afikpo Formations in the Anambra Basin.

\section{Mamu Formation (Lower Maastrichtian)}

The Mamu Formation consists of alternating sandstone, sandy shales, and mudstones with interbedded coal seams. The Formation is underlain by the Campanian Enugu/Nkporo shales (lateral equivalents) and Nsukka Formation (Upper Maastrichtian) to Danian. Five sedimentary units were recognized in the Mamu Formation in the Enugu area where the thickest exposed section (approximately $80 \mathrm{~m}$ ) occurs. The basal units consist of shale or sandy shale, sandstone with occasional shale beds, carbonaceous shale, coal seams, and sandy shale (Simpsons, 1954; Reyment, 1965) (Figure 3).

\section{Ajali Formation}

The Ajali sandstone overlies the Mamu Formation and it has a diachronous age from South to the North (middle - late Maastrichtian). In addition, it exhibits significant thickness variation from less than $300 \mathrm{~m}$ to over $1000 \mathrm{~m}$ at the centre of the basin. Depositional characteristics are uniform for most parts of the basin, and it is made up of textually mature sand facies i.e. mature quartz arenite intercalated with kaolinite beds (Figure 3).

\section{Nsukka Formation}

Nsukka Formation, which overlies the Ajali Sandstone, begins with coarse- to medium-grained sandstones and passes upward into well-bedded blue clays, fine-grained sandstones, and carbonaceous shales with thin bands of limestone (Reyment, 1965; Obi et al., 2001) (Figure 3).

\section{The Imo Formation}

The Imo Formation consists of blue-grey clays and black shales with bands of calcareous sandstones, marls, and limestone (Reyment, 1965). Ostracods and foraminifera biostratigraphy (Reyment, 1965), and microfauna recovered from the basal limestone unit (Adegoke et al., 1980; Arua, 1986), indicate a Paleocene age for the formation. The Imo Formation is the outcrop lithofacies equivalent of the Akata Formation in the subsurface Niger Delta (Short \& Stauble, 1967; Avbovbo, 1978).

\section{Ameki Group}

The Ameki Group consists basically of the Nanka Sand, Nsugbe Formation, and Ameki Formation (Nwajide, 1979), which are laterally 
equivalents. The age of the formation has been considered to be either early Eocene (Reyment, 1965) or early to middle Eocene (Berggren, 1960; Adegoke, 1969). The depositional environment has been interpreted as estuarine, lagoonal, and open marine based on the faunal content. White (1926) interpreted an estuarine environment because of the presence of fish species of known estuarine affinity. Adegoke (1969), however, indicated that the fish were probably washed into the Ameki Sea from inland waters, and preferred an open marine depositional environment. Nwajide (1979) and Arua (1986) suggested environments that ranged from nearshore (barrier ridgelagoonal complex) to intertidal and subtidal zones of the shelf environments. Furthermore, Fayose and Ola (1990) also reported that the sediments have marine inputs with waters depths of about $10 \mathrm{~m}$ and $100 \mathrm{~m}$.

\section{The Ogwashi-Asaba Formation}

The Ogwashi-Asaba Formation comprises of alternating coarsegrained sandstone, lignite seams, and light coloured clays of continental origin (Kogbe, 1976). Reyment (1965) suggested an Oligocene-Miocene age for the formation, while Jan du Chene et al. (1978) reported middle Eocene age for the basal part from palynology. The Ameki Group and the Ogwashi- Asaba Formation are correlative with the Agbada Formation in the surface Niger Delta. Subsequently, Akande $(1993,1998)$ stated that there is increasing attention to the geochemistry of the southern Benue basins. Akande (2015) also reported that different methane precursors in the interbedded coal and shale lithologies suggest remarkable potential to contribute a mixture of hydrocarbons derived from marine and terrestrial organic matters. The coal and coaly shale are not within the thermally mature stratigraphic levels in the outcrop, but in the sub-surface level of Agbada formation. Hence, they are potential source rocks for hydrocarbons generation in the Niger Delta.

\section{Methodology}

The exposed rock units at the Ogbunike quarry have been described, sampled, and logged. Seventy seven (77) rock samples of varying facies including shale, sandstones, claystone, and siltstone were carefully sampled from four locations within the quarry. A total of twenty (20) samples of shale were collected, pulverized, and analyzed for Total Organic Carbon (TOC) by means of LECO-CS analyzer. Standard methods of pulverization and treatment with hydrochloric acid $(\mathrm{HCl})$ for carbonate removal were employed.

This was before $100 \mathrm{mg}$ of each sample was measured and weighed.

Twelve (12) shale samples were analyzed for their microfossil contents. $200 \mathrm{~g}$ of each sample were weighed and dried so as to remove the moisture content in the shale. Solution of concentrated hydrogen peroxide $\left(\mathrm{H}_{2} \mathrm{O}_{2}\right)$ was diluted with water in a ratio $1: 3$ i.e. $100 \mathrm{ml}$ of $\mathrm{H}_{2} \mathrm{O}_{2}$ reacting with $300 \mathrm{ml}$ of water. The 
solution was poured into the weighed shale sample which was already prepared in a container for digestion. The mixture was left for 24 hours for proper digestion after which washing was done using $0.063 \mathrm{~mm}$ sieve under running water. The residues were air dried and stored carefully in well labelled sealed plastic bottles. Thus, this was followed by the picking, identification, and description of the foraminifera species under the binocular microscope. This was done to identify the species and their occurrence to enable depositional environment reconstruction.

The Rock-Eval pyrolysis technique of Espitalie (1977) provides data on the quantity, type, and thermal maturity of the associated organic matter for the twenty (20) shale samples. This was carried out at the Organic Geochemistry laboratory of Australian Laboratory Services (ALS), Empirical Laboratory Houston, Texas, USA. The samples were heated under an inert atmosphere of helium at $300^{\circ} \mathrm{C}$ for 3-4 min and then pyrolysed at $25^{\circ}$ $\mathrm{C} /$ minute to $600^{\circ} \mathrm{C}$, followed by posterior cooling down for the next sample to be run. The pyrolysis values obtained include Tmax, $S_{1}, S_{2}$, and $S_{3}$. These parameters were further used to evaluate the hydrogen index, oxygen index, production index which are indicative of the level of maturity of the organic matter, the type or types of organic matter, and the amount of hydrocarbons already produced or that can be produced from a studied rock sample.

The whole rock and trace elements analyses were carried out at Activation laboratory (Actlab) Ancaster, Ontario, Canada, on eleven (11) selected shale samples using ICP-OES and ICP-MS. This fusion technique involves a lithium metaborate /teraborate fusion. The fusion procedures consist of heating a mixture of sample and flux at high temperature (800-1200 ${ }^{\circ} \mathrm{C}$ ) so that the flux melts and the sample dissolves. The overall composition and cooling conditions is such that the end product after cooling is one phase glass. The resulting molten bead is rapidly digested in a weak nitric acid solution. The fusion ensures the entire sample is dissolved. For trace element analysis, $0.25 \mathrm{~g}$ of the sample was digested with four acids beginning with hydrofluoric, followed by a mixture of nitric and hydrochloric acids, heated using precise programmer controlled heating in several ramping and heating cycles which takes the samples to dryness. After dryness is attained, samples are brought back into the solution using hydrochloric acid. The sample solution was then analyzed for elemental concentration using Perkin Elmer Optima 3000 ICP. Calibration was performed using USGS and CANMET certified reference materials. 


\section{Results and Discussion \\ Depositional Environments Interpretation \\ Lithofacies and Sedimentology}

The rock facies identified at the Ogbunike quarry are essentially sandstones, siltstones, shales, and claystone which are indicative of various depositional environments and conditions in the basin. The lithological sections were drawn and described at four locations labelled OB1, OB2, OB3, and OB4 along a depositional strike trending NW-SE in the quarry. In addition, distinct variations in the lithofacies were observed vertically up the section and horizontally along the bedding planes (Figure 4).

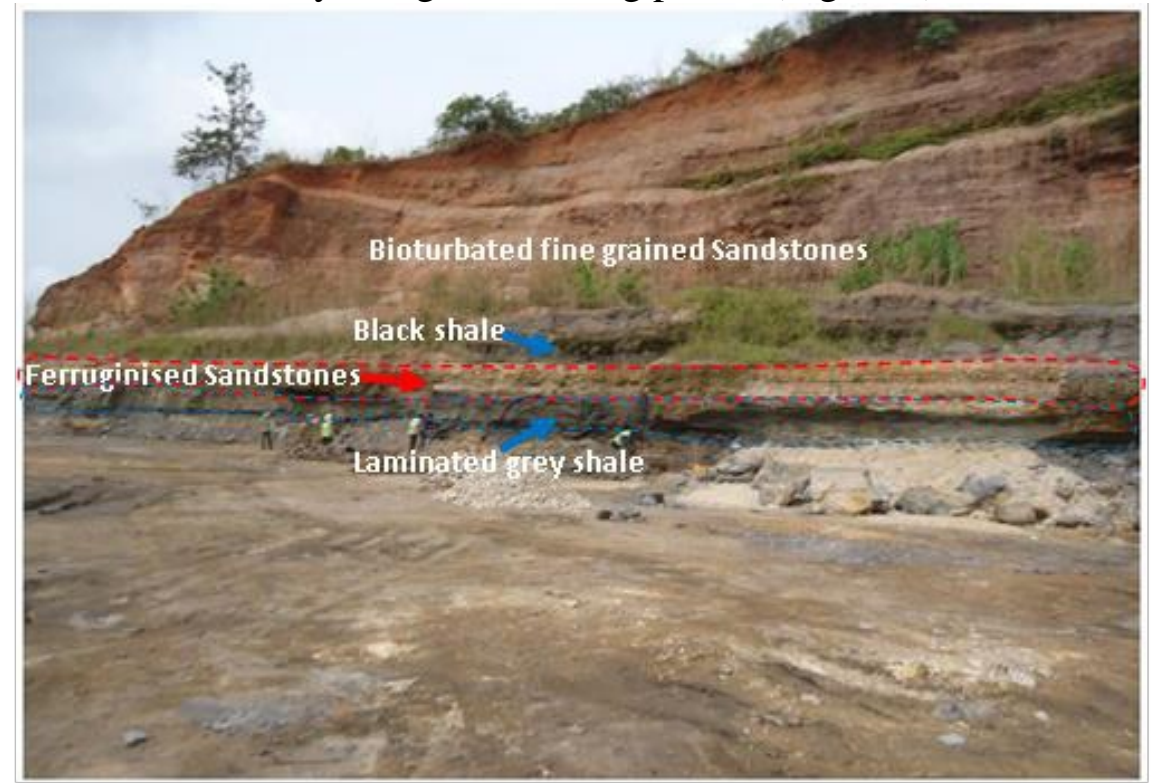

Figure 4. Field photograph of Bende - Ameki Formation exposed at Ogbunike quarry showing some of the lithofacies.

At location OB1 in the northernmost part of the quarry, the basal sandstone is medium grained and bioturbated overlained by a ferruginised fine grained facies. The bioturbation shows an intense oxidation before a transition into a parallel laminated dark grey shale overlained by highly ferruginised bioturbated claystone and capped by ferruginised sandstones. The above described sedimentation pattern at location OB1 was observed in all the locations except that at location 2 (OB2) and 3 (OB3) (Figure 5). Here, the thickest sections which exist have more of laminated dark to black coaly shales. The parallel laminated features of the shales suggest possible water stratification during the period of quietness in the basin. The lamination shows that the effect of tide, waves or other high energy related agent of deposition, are minimal. Also, a relatively deep-water environment, which may not be 
well sustained, prevailed. The features suggest a lagoonal and swamps depositional environments passing into open shelf facies.

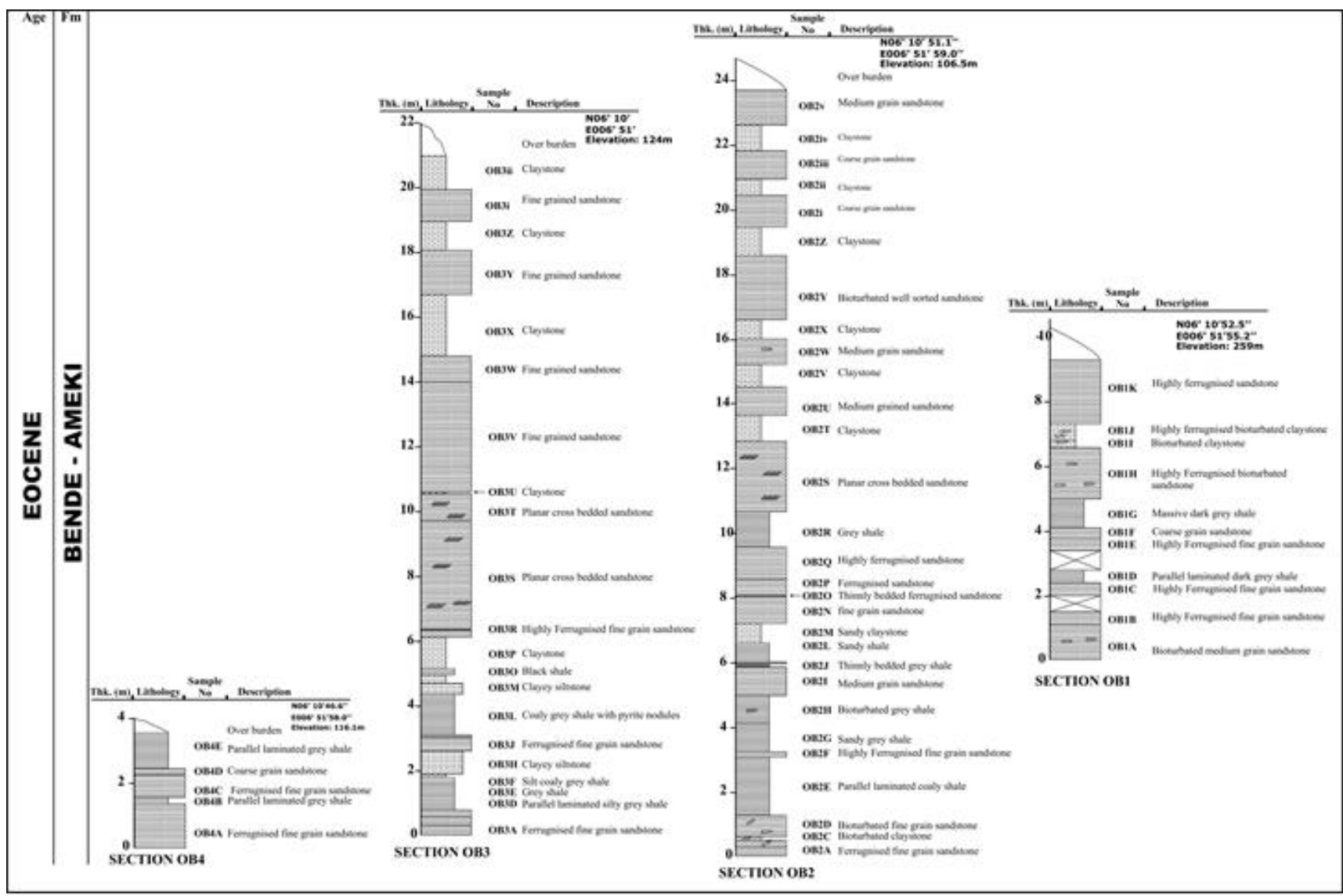

Figure 5. Composite lithologic sections of the Bende - Ameki Formation exposed at Ogbunike

\section{Benthic Foraminifera Occurrence}

Benthic foraminifera of the Ammobaculites, Amotium, Buliamina, Lenticulina, Reophax and Textularian genus were found in the shale. They are few with low diversity and small sized body structure which is commonly attributed to a harsh or unconducive environmental conditions as well as insufficient nutrient to support large population. The Ammobaculites being an infaunal deposit feeder is commonly found in long range habitat from marsh, estuaries, brackish to neritic, and bathyal environments. However, they can tolerate low oxygen levels (Culver \& Buzas, 1981; Koutsoukos et al., 1990; Murray, 1991). Ammotium are generally restricted to shallow brackish waters (Murray, 1968, 1991; Bronnimann, 1992). Lenticulina prefers cool marine conditions on the outer shelf to bathyal depth (Murray, 1991). They are indicative of high phytodetritus influx and dysoxic bottom water, an indication 
of marine influences to the organic matter constituents of the shale, which can enhance its potential as hydrocarbon source rocks.

\section{Trace Elements}

The relative abundance of trace elements and oxides in sediment is controlled by sedimentation rate, terrigenous influx, biogenic influx, hydrothermal input, diagenesis and, ultimately, weathering (Leventhal, 1998; Schieber \& Zimmerle, 1998). Their enrichments can lead to understanding of their paleo-depositional and paleo redox setting, as well as the paleo-climate (Vine \& Tourtelot, 1970). The $\mathrm{pH}$ and Eh conditions has a significant impact on the environments as those sensitive to redox conditions are more soluble under oxidizing conditions and are less soluble under reducing conditions. Therefore, the concentration of these redox-sensitive elements, such as $\mathrm{V}, \mathrm{Ni}$, $\mathrm{Cu}, \mathrm{Cr} \mathrm{Mo}$, and $\mathrm{Co}$ (Table 1), were sensitive indicators of prevalence paleoconditions (Adegoke et al., 2014). The concentration of vanadium (V), and nickel $(\mathrm{Ni})$ as well as their ratios provide a means of determining the degree of anoxia during deposition (Barwise, 1990; Bechtel et al., 2001; Galarraga et al., 2008). Vanadium is usually enriched in comparison with $\mathrm{Ni}$ in anoxic marine environments (Peters \& Moldowan, 1993). This is due to strong activities of the sulfate reduction bacteria in this environment and greater relative stability of vanadyl versus nickel porphyrin complexes. The reverse is the case under normal oxic conditions (Lewan, 1984).

Table 1. Trace elements concentration in ppm of shales from Ogbunike

\begin{tabular}{|c|r|r|r|r|r|r|r|r|r|r|r|r|r|}
\hline Samples & \multicolumn{1}{|c|}{$\mathbf{V}$} & $\mathbf{C r}$ & \multicolumn{1}{|c|}{$\mathbf{N i}$} & $\mathbf{C u}$ & $\mathbf{Z n}$ & $\mathbf{B a}$ & $\mathbf{V} / \mathbf{C r}$ & $\mathbf{C o}$ & $\mathbf{N i} / \mathbf{C o}$ & $\mathbf{V} / \mathbf{N i}$ & $\mathbf{V} /(\mathbf{V}+\mathbf{N i})$ & $\mathbf{V}+\mathbf{N i}$ & $\mathbf{V} / \mathbf{C r}$ \\
\hline OB1D & 90 & 130 & 42 & 15 & 31 & 427 & 0.69 & 14 & 3.00 & 2.14 & 0.68 & 132 & 0.69 \\
\hline OB1G B & 103 & 140 & 52 & 17 & 31 & 559 & 0.74 & 21 & 2.48 & 1.98 & 0.66 & 155 & 0.74 \\
\hline OB1G M & 116 & 150 & 69 & 18 & 37 & 714 & 0.77 & 29 & 2.38 & 1.68 & 0.63 & 185 & 0.77 \\
\hline OB1G T & 99 & 150 & 72 & 26 & 33 & 787 & 0.66 & 39 & 1.85 & 1.38 & 0.58 & 171 & 0.66 \\
\hline OB2E & 103 & 130 & 36 & 11 & 26 & 743 & 0.79 & 15 & 2.40 & 2.86 & 0.74 & 139 & 0.79 \\
\hline OB2G & 35 & 30 & 16 & 10 & 14 & 592 & 1.17 & 5 & 3.20 & 2.19 & 0.69 & 51 & 1.17 \\
\hline OB2H B & 142 & 140 & 63 & 16 & 106 & 648 & 1.01 & 34 & 1.85 & 2.25 & 0.69 & 205 & 1.01 \\
\hline OB2R M & 152 & 160 & 89 & 22 & 130 & 357 & 0.95 & 42 & 2.12 & 1.71 & 0.63 & 241 & 0.95 \\
\hline OB3F & 84 & 90 & 44 & 10 & 209 & 881 & 0.93 & 21 & 2.10 & 1.91 & 0.66 & 128 & 0.93 \\
\hline OB3O & 139 & 140 & 65 & 23 & 55 & 204 & 0.99 & 29 & 2.24 & 2.14 & 0.68 & 204 & 0.99 \\
\hline OB4E & 115 & 140 & 51 & 14 & 132 & 917 & 0.82 & 21 & 2.43 & 2.25 & 0.69 & 166 & 0.82 \\
\hline
\end{tabular}

According to Galarraga et al. (2008), a V/Ni ratio greater than 3 suggest that the organic matter were deposited in a reducing environment, while $\mathrm{V} / \mathrm{Ni}$ ratios ranging from 1.9 to $3 \mathrm{ppm}$ indicates dysoxic-oxic conditions. The distribution of the trace elements in the investigated shales revealed that vanadium ion concentrations are generally more than the 
concentrations of nickel ion. The $\mathrm{V} / \mathrm{Ni}$ ration ranging between $1.91-2.86$ was observed in eight (8) of the black shales, while the remaining three were below 1.9 , thus suggesting that they are mixed marine and terrigenous organic matter under dysoxic to oxic conditions (Figure 6). Adegoke et al. (2014) reported $\mathrm{V} /(\mathrm{V}+\mathrm{Ni})$ value of $0.69-0.76 \mathrm{ppm}$ in the Gongila shale, Chad Basin, in the northeastern Nigeria indicating that they might have been deposited in a dysoxic environment. This occurrence is similar to the observed values of 0.68 -0.74 from the Ogbunike shales, while some interbeding units have values lower than the bench mark suggesting the contributions of an oxidizing conditions at such intervals.

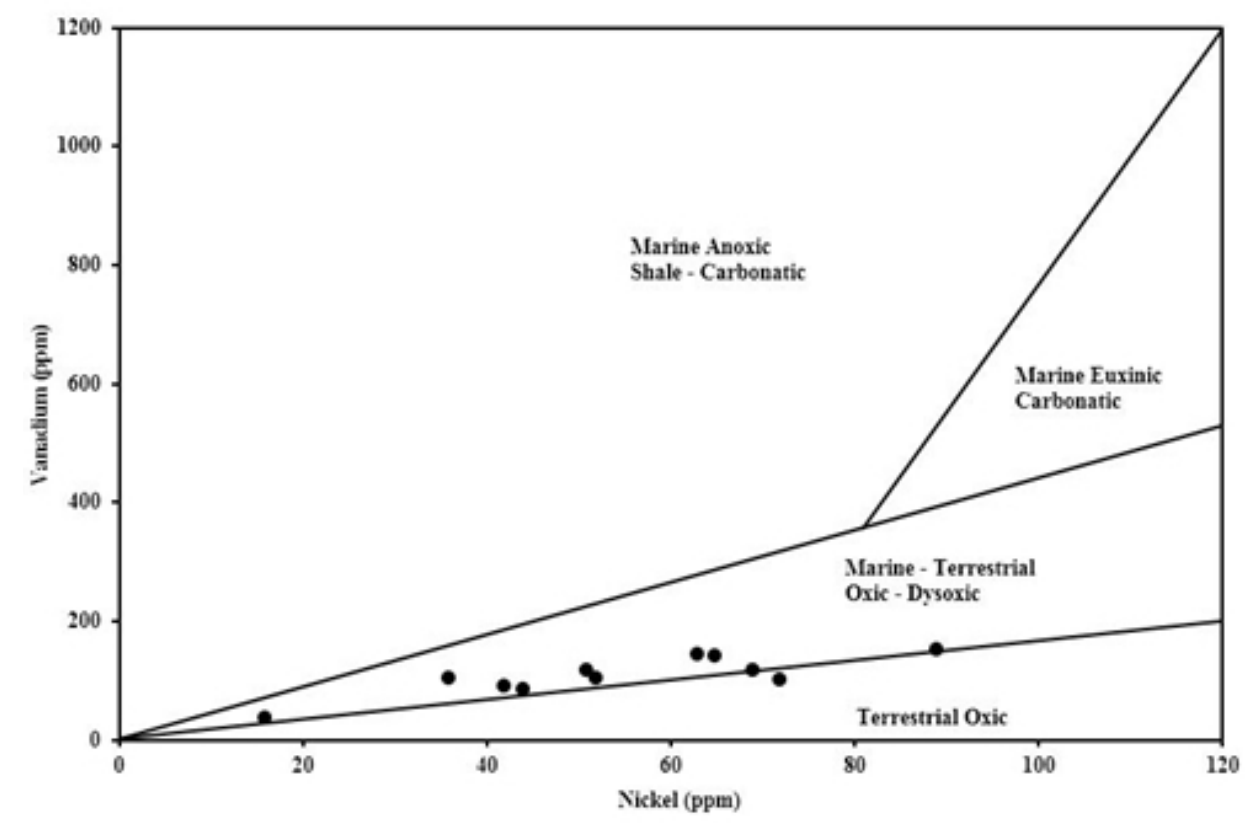

Figure 6. Cross plot of vanadium versus nickel of shale samples from Ogbunike quarry, Anambra Basin, showing that the organic matter had mixed marine and terrigenous source input and were deposited under oxic - dysoxic conditions (modified after Galarraga et al., 2008).

Similarly, the V/Cr ratio has been used as a paleo-oxygenation indicator in a number of studies. Values of $\mathrm{V} / \mathrm{Cr}>2$ are thought to represent anoxic depositional conditions, whereas values below 2 are indicative of more oxidizing conditions (Dill et al., 1988). The shales have $\mathrm{V} / \mathrm{Cr}$ values (Table 1), which may indicate that relatively oxidizing conditions was also prevalent. In addition, a Ni/Co ratio above 5 indicates dysoxic to anoxic environment, whereas a ratio below 5 suggests an oxic environment (Jones \& Manning, 1994). All the shales have Ni/Co ratio below 5 , which suggests prevailing oxidizing conditions. 


\section{Petroleum Potentials}

The total organic carbon of the twenty (20) shales range from $0.39-$ $8.81 \mathrm{wt} \%$ with an average value of $2.3 \mathrm{wt} \%$. Generally, most of the shales have TOC value $1.0 \mathrm{wt} \%$ which depicts a good to very good source rock (Peter \& Cassa, 1994). The TOC concentration correlates with the lithofacies in such a way that the $0.39 \mathrm{wt} \%$ was from the sandy shale units, while the remaining nineteen samples which represent $95 \%$ of the shales have TOC values greater than $1.1 \mathrm{wt} \%$. The laminated greyish to black shales have TOC values in the range 3.15 to $8.18 \mathrm{wt} \%$ that occurs within the base of the section within $2 \mathrm{~m}$ to $6 \mathrm{~m}$ depth across the quarry. The organic carbon in the sediments alone can only identify potential oil source beds. If it is hydrogen poor, it will be gas prone or inert, and without any significant oil generating potential (Tissot et al., 1974; Demaison \& Moore, 1980).

The type of hydrocarbons a source rock can generate is dependent on its kerogen constituents. Kerogen have been classified into four types based on their hydrogen indices (HI), which is the derivative of $\mathrm{S}_{2}$ and TOC, which is proportional to the amount of hydrogen contained within the kerogen (Tissot et al., 1974; Tissot \& Welte, 1984; Peter \& Cassa, 1994; Dembicki, 2009). The Ogbunike shales have HI values ranging from $26-292 \mathrm{mgHC} / \mathrm{gTOC}$ (mean $=67 \mathrm{mgHC} / \mathrm{gTOC}$ ) $($ Table 2$)$. The laminated, greyish to black shale, have HI that ranges from $77-292 \mathrm{mgHC} / \mathrm{gTOC}$ suggesting Type II-III mixed oil and gas prone kerogen which correlate with the TOC contents (Figure 7). This interval at the basal part of the quarry represents the most promising in respect to hydrocarbon generation at maturity. The less than $50 \mathrm{mgHC} / \mathrm{gTOC}$ are from the bioturbated and sandy shale units. They indicate prevalence of oxidized Type IV inert kerogen from a highly reworked terrestrially derived organic matter.

Table 2. TOC and Rock-Eval data of the shale samples from Ogbunike quarry.

\begin{tabular}{|c|c|c|c|c|c|c|c|c|c|}
\hline S/N & SAMPLE NO. & TOC & $\mathbf{S}_{\mathbf{1}}$ & $\mathbf{S}_{\mathbf{2}}$ & $\mathbf{T m a x}$ & $\mathbf{S}_{\mathbf{3}}$ & $\mathbf{H I}$ & OI & PI \\
\hline 1 & OB1D & 3.94 & 0.34 & 3.43 & 411 & 1.09 & 87 & 27 & 0.09 \\
\hline 2 & OB1GB & 1.48 & 0.09 & 0.40 & 403 & 0.69 & 26 & 46 & 0.18 \\
\hline 3 & OB1GT & 1.59 & 0.10 & 0.54 & 401 & 0.73 & 34 & 45 & 0.16 \\
\hline 4 & OB2E & 3.15 & 0.29 & 2.43 & 409 & 1.05 & 77 & 33 & 0.11 \\
\hline 5 & OB2G & 0.39 & 0.05 & 0.17 & 408 & 0.19 & 42 & 49 & 0.24 \\
\hline 6 & OB2HB & 1.45 & 0.10 & 0.53 & 402 & 0.45 & 36 & 31 & 0.16 \\
\hline 7 & OB2HT & 1.14 & 0.08 & 0.38 & 400 & 0.47 & 33 & 41 & 0.17 \\
\hline 8 & OB2RB & 2.99 & 0.27 & 2.69 & 420 & 0.90 & 89 & 30 & 0.09 \\
\hline 9 & OB2RM & 2.64 & 0.24 & 3.15 & 424 & 0.72 & 119 & 27 & 0.07 \\
\hline 10 & OB2RT & 2.51 & 0.23 & 2.95 & 424 & 0.93 & 117 & 36 & 0.07 \\
\hline 11 & OB3DB & 1.17 & 0.04 & 0.45 & 406 & 0.62 & 38 & 53 & 0.08 \\
\hline 12 & OB3DT & 1.09 & 0.07 & 0.51 & 409 & 0.45 & 46 & 41 & 0.12 \\
\hline 13 & OB3EB & 1.12 & 0.08 & 0.40 & 405 & 0.63 & 35 & 56 & 0.17 \\
\hline
\end{tabular}




\begin{tabular}{|l|c|c|c|c|c|c|c|c|c|}
\hline 14 & OB3ET & 1.79 & 0.10 & 0.69 & 406 & 0.76 & 38 & 42 & 0.13 \\
\hline 15 & OB3F & 1.46 & 0.07 & 0.42 & 410 & 0.79 & 28 & 54 & 0.14 \\
\hline 16 & OB3LB & 1.31 & 0.06 & 0.38 & 403 & 0.62 & 28 & 46 & 0.15 \\
\hline 17 & OB3LT & 2.53 & 0.13 & 1.08 & 412 & 0.98 & 42 & 38 & 0.11 \\
\hline 18 & OB3O & 8.81 & 1.61 & 25.74 & 424 & 1.64 & 292 & 18 & 0.06 \\
\hline 19 & OB4B & 4.07 & 0.33 & 4.34 & 415 & 1.29 & 106 & 31 & 0.07 \\
\hline 20 & OB4E & 1.75 & 0.08 & 0.58 & 410 & 0.86 & 33 & 49 & 0.13 \\
\hline
\end{tabular}

TOC (Wt \%), $\mathrm{S}_{1}, \mathrm{~S}_{2}$ (mgHC/g rock), $\mathrm{S}_{3}$ (mgCO $/$ grock), Tmax $\left({ }^{\circ} \mathrm{C}\right), \mathrm{HI}$ (mgHc/gTOC), OI, PI

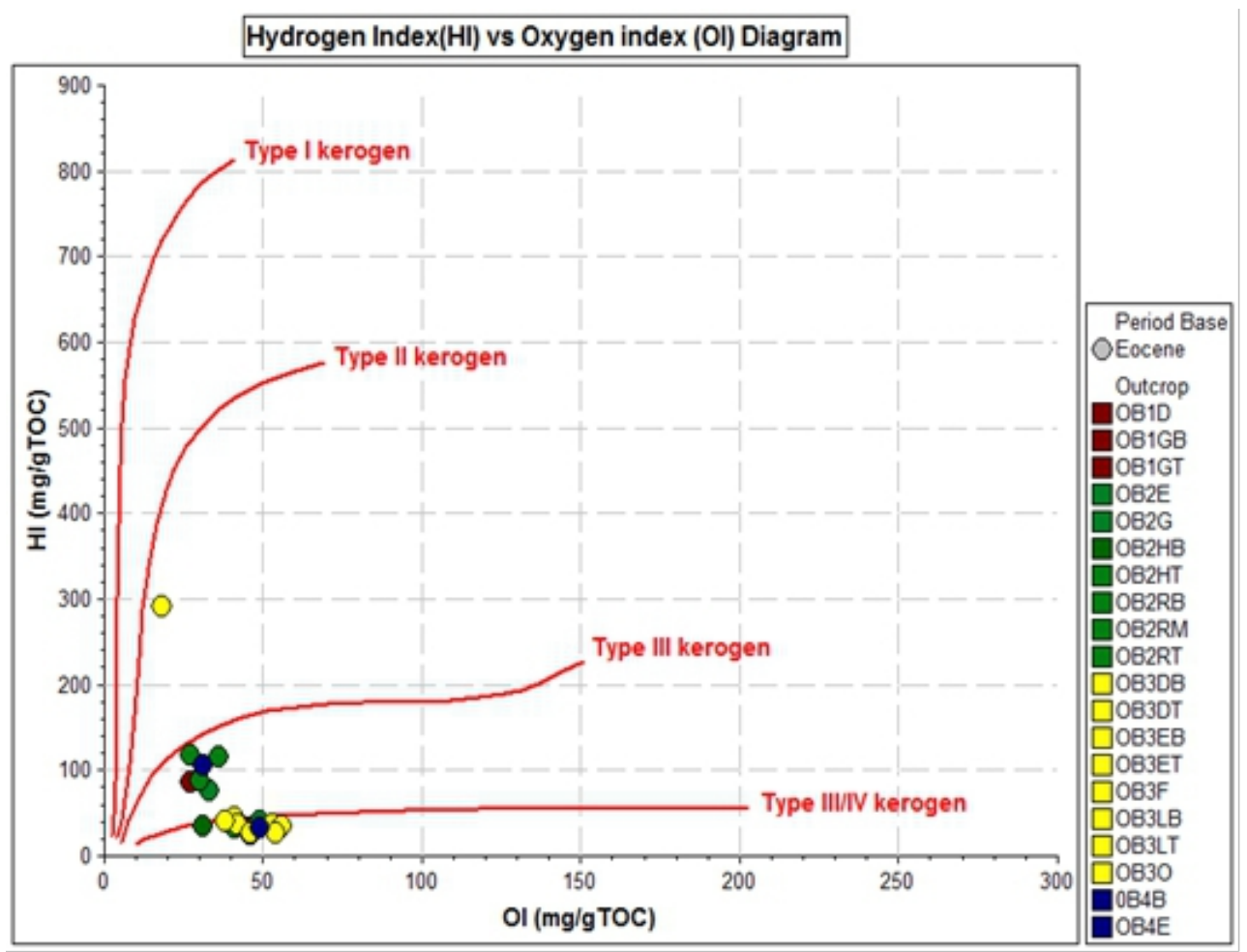

Figure 7. Van Krevelen Hydrogen Index versus Oxygen Index plot of the organic matter from the Bende-Ameki Formation at Ogbunike.

The source potential values for the investigated shales range from 0.22 $-25.74 \mathrm{kgHC} / \mathrm{ton}$ of rock (mean of $2.78 \mathrm{kgHC} / \mathrm{ton}$ of rock). The value ranging from 0.22 - 1.21 indicates poor hydrocarbon potential, values ranging from 2.72 - 4.67 indicate fair to moderate hydrocarbon potential, and above 5.0 $\mathrm{kgHC}$ ton of rock suggest excellent potential for hydrocarbons. It was noted that the $25 \mathrm{~cm}$ thick (OB3O) black shale unit have source potential of 27.35 $\mathrm{kgC} /$ ton of rock (Table 2, Figure 8) which is consistent with the TOC of 8.81 $\%$ and $292 \mathrm{mgHC} / \mathrm{gTOC}$ hydrogen index. Thus, this indicates a good source of hydrocarbon generation at maturity. Asides the OB3O units and other laminated black shales unit, all other intervals have very low generative potential. 


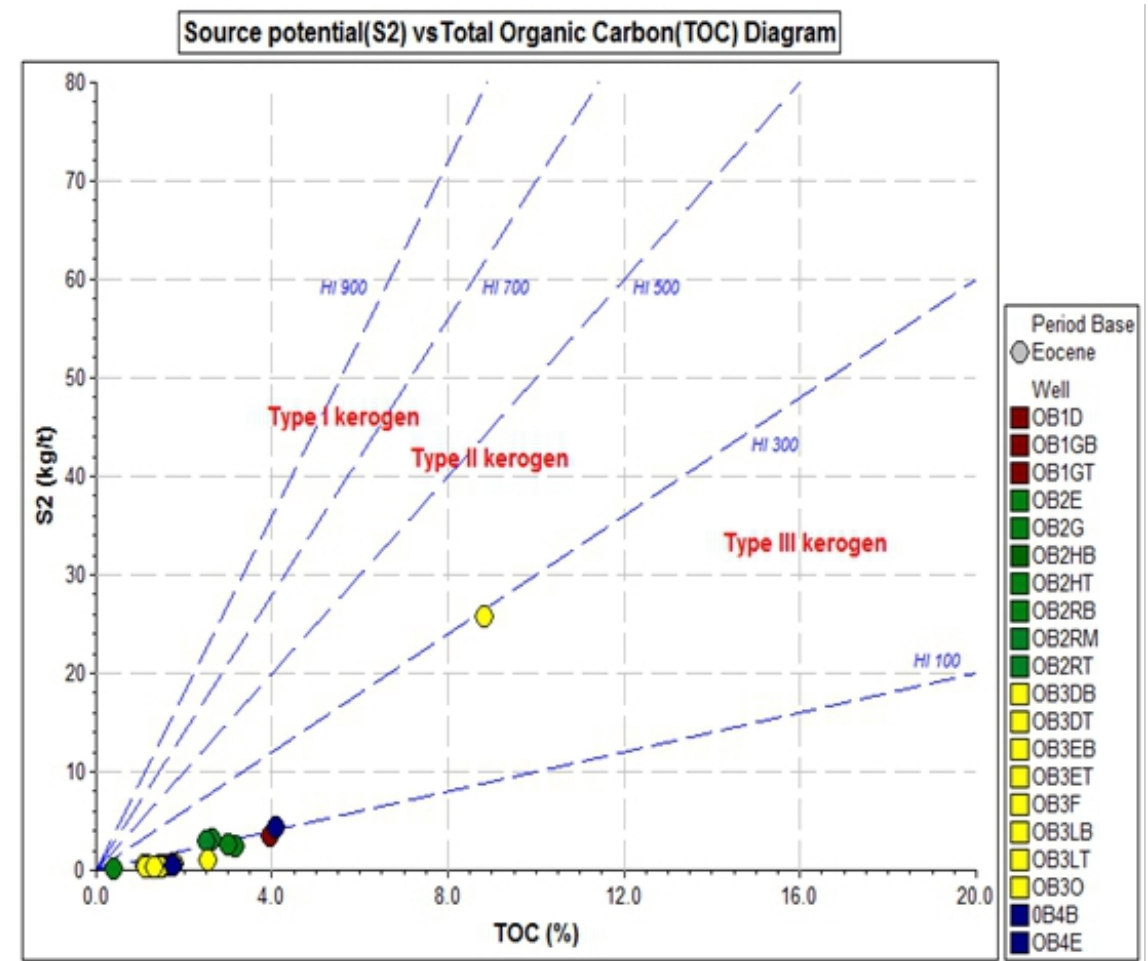

Figure 8. Source Potential (S2 kg/t) versus Total Organic Carbon (TOC wt \%) of the studied shales at Ogbunike.

\section{Thermal Maturity}

Tmax measures thermal maturity based on the Rock-Eval pyrolysis oven temperature at maximum $\mathrm{S}_{2}$ generation. T-max is not an equivalent of geologic temperatures attained. It is partly determined by the type of organic matter (Peters, 1986), the temperature gradient in the basin, which is mainly controlled by the basal heat flow through time and burial depth of the sediments and time (Peter \& Cassa, 1994). The significance of Tmax with maturation of a source can also be understood by realizing that organic compounds with smaller activation energies generate petroleum faster than organic compound with larger activation energies (Nordeng, 2012). Hence, the maturation level of a kerogen may be estimated from Tmax. Tmax value of the shales in range from $401-424{ }^{\circ} \mathrm{C}$, with an average $410{ }^{\circ} \mathrm{C}$, indicates that they are immature at the current outcrop level (Figure 9). 


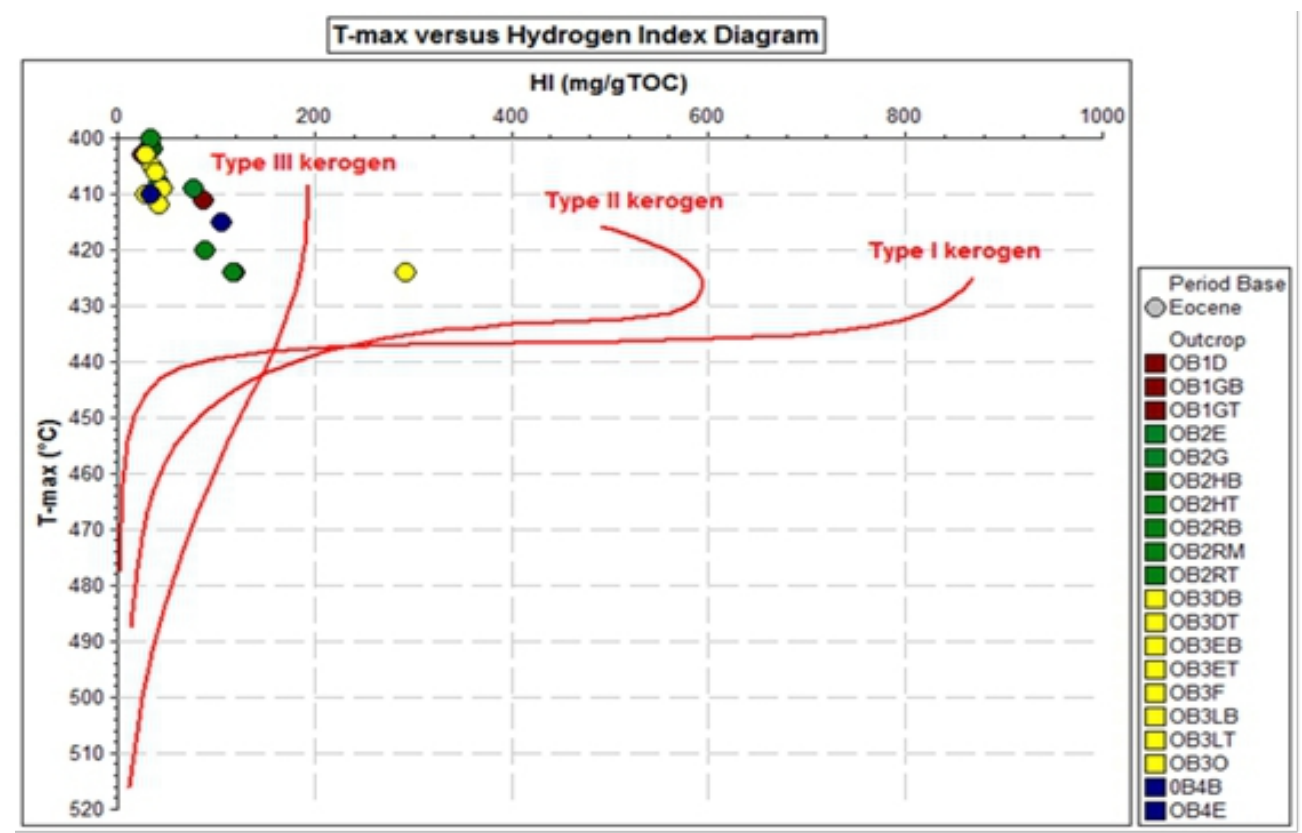

Figure 9. HI against Tmax $\left({ }^{0} \mathrm{C}\right)$ diagram for the interpretation of kerogen types and maturity of the Bende-Ameki shales at Ogbunike.

\section{Conclusions}

The Ogbunike section consists of shales, claystones, siltstones, and sandstones with a coarsening upward sequence representing lithofacies of the Bende - Ameki formation; an outcropping equivalent of the Niger Delta succession in the subsurface. The sandstones are probably shoreface sands, barrier islands near the coastline.

The shale facies in the quarry are most promising at the base of the section within $2 \mathrm{~m}$ to $6 \mathrm{~m}$. They are grey, dark to black, silty, and laminated with some biofacies representing a lagoonal environment to open shelf facies. They have the highest total organic carbon contents and hydrogen index. They are therefore characterized as good source rock.

However, these source rocks of Eocene Bende - Ameki Formation at Ogbunike are currently immature at the present outcrop level, but they have a fair to moderate potential to generate gaseous hydrocarbons at mature levels in the subsurface.

\section{References:}

1. Adegoke, A. K., Abdullahi, W. H., Hakimi M. H., Yandoka, B. M. S., Mustapha, K. A., \& Aturamu A. O. (2014). Trace element geochemistry of kerogen in the Upper Cretaceous sediments Chad (Bornu) Basin, northeastern Nigeria; Origin paleoredox condition.Journ. Afr. Earth Sci. 100,675-683. 
2. Adegoke, O. S., Arua, I., \& Oyegoke, O. (1980). Two new nautiloids from the Imo Shale, (Paleocene) and Ameki Formation (Middle Eocene), Anambra State, Nigeria. Journal of Mining and Geology 17, 85-89.

3. Adegoke, O. S. (1969). Eocene stratigraphy of southern Nigeria.Colloque sur $l_{-}$Eocene, III. Bureau de Recherches Geologiques et Minieres 69, 22-48

4. Akaegbobi, I. M., Nwachukwu, J. I., \& Schmitt, M. (2000). Aromatic Hydrocarbon Distribution and Calculation of Oil and Gas Volumes in Post-Santonian shale and coal, Anambra Basin, Nigeria. In M. R. Bello and B. J. Katz, eds., Petroleum systems of South Atlantic margins: AAPG Memoir 73, p.233-245.

5. Akande, S.O., Ojo, O. J., Erdtmann, B. D., \& Hetenyi, M. (1998). Paleoenvironments, source rock potential and thermal maturity of the Upper Benue rift basins, Nigeria: Implications for hydrocarbon exploration. Organic Geochemistry v. 29, p. 531-542.

6. Akande, S. O., Ojo, O. J., Adekeye, O. A., Bankole, S. I., Ocheje, E., Adeoye, J. A., \& Abikoye, T. V. (2010). Hydrocarbon source rocks evaluation in the Cretaceous to Neogene Basins of Southern Nigeria and implications for the Niger Delta petroleum systems. PTDF Compendium of Oil and Gas Research pg. 1 - 84.

7. Akande, S. O., \& Mucke, A. (1993). Depositional environment and diagenesis of carbonates at the Mamu/Nkporo Formation, Anambra Basin, Southern Nigeria. Journal of African Earth Sciences, v. 17, no. 4, p. $445-456$.

8. Akande, S. O., Lewan, M.D., Egenhoff, S., Adekeye O.A., Ojo, O.J., \& Peterhansel, A. (2015). Source rock potential of lignite and interbedded coaly shale of the Ogwashi Asaba Formation, Anambra Basin as determined by sequential hydrous pyrolysis. International Journal of Coal Geology 150-151 (2015) 224-237.

9. Arua, I. (1986). Paleoenvironments of Eocene deposits in the Afikpo Syncline, southern Nigeria. Journal of African Earth Sciences 5, 279284

10. Avbovbo, A.A. (1978). Tertiary lithostratigraphy of the Niger Delta. American Association of Petroleum Geologists Bulletin 62, 295 - 306

11. Barwise, A. J. G. (1990). Role of Nickel and vanadium in petroleum classification. Energy fuels 4, 27- 49.

12. Bechtel, A., Gratzer, R., \& Sachsenhofer, R.F. (2001). Chemical characteristics of Upper Cretaceous (Turonian) jet of the Gosau Group of Gams/Hieflau (Styria, Austria). Int. J. Coal Geol. 46, 27-49. 
13. Berggren, W. A. (1960). Paleocene biostratigraphy and planktonic foraminifera of Nigeria (West Africa). International Geological Congress, Copenhagen, Report 21 (6), 41-55.

14. Brönnimann, P., Whittaker, J. E., \& Zaninetti, L. (1992). Brackish water foraminifera from mangrove sediments of southwestern Viti Levu, Fiji Island, southwest Pacific: Revue de Paléobiologie, v. 11, no. 1, p. 13-65.

15. Culver, S. J. \& Buzas, M. A. (1981). Distribution of selected recent benthic foraminiferal general in the western North Atlantic, in Neale, J. W., and Brazier, M. D. (eds.), Microfossils from recent and fossil shelf seas: British Micropalaeontological Society Series, Ellis Horwood Limited, Chichester, p. 336-349.

16. Demaison, C. J. \& Moore, G. T. (1980). Anoxic environments and oil source bed genesis. The American association of Petroleum Geologists Bulletin, V. 64, No. 8, p. $1179-1209$.

17. Dill, H., Teschner, M., \& Wehner, H. (1988). Petrography, inorganic and organic geochemistry of Lower Permian carbonaceous fan sequences ("Brand schiefer Series") Federal Republic of Germany: constraints to their paleogeography and assessment of their source rock potential. Chem. Geol. v. 67, 307 - 325.

18. Espitalie, J., Marquis, F., \& Barsony, I. (1977). Geochemical logging. In: Voorhees, K. J. eds., Analytical Pyrolysis - Techniques and Application, Butterworth, Guilford, p.276-30.

19. Fayose, E. A. \& Ola, P. S. (1990). Radiolarian occurrences in the Ameki type section, eastern Nigeria. Journal of Mining and Geology 26, 75-80.

20. Galarraga, F., Reategui, k., Martinez, M., Liamas J.F., \& Marquez, G. (2008). V/Ni ratio as a parameter in paleoenvironmental characterization of non-mature medium crude oils from Latin American Basin. Journ. Petrol. Sci. Eng. 61, 9- 14.

21. Jan du Che^ne, R., Onyike, M. S., \& Sowumi, M. A. (1978). Some new Eocene pollen of the Ogwashi-Asaba Formation, South eastern Nigeria. Revista de Espanol Micropaleontologie 10, 285 - 322.

22. Jones, B. \& Manning, D.C. (1994). Comparison of geochemical indices used for the interpretation of paleo-redox conditions in Ancient mudstones: Chemical Geology, 111(1-4), 111-129.

23. Kogbe, C. A. (1976). Paleogeography History of Nigeria since the Albian times. In: C.A Kogbe (ed).Geology of Nigeria pp 237252.Elizbetthan Publ. Co. Lagos.

24. Koutsoukos, E. A., Leary, P. N., \& Hart, M. B. (1990). Latest Cenomanian-Earliest Turonian low- oxygen tolerant benthonic foraminifera: a case study from the Sergipe Basin (N.E Brazil) and the 
western Anglo-Paris Basin (Southern England). Palaeogeography, Palaeoclimatology, Palaeoecology, Amsterdam, v. 77, p.145-177.

25. Leventhal, J. S. (1998). Metal-rich black shales: formation, economic geology and environmental considerations. In Shales and Mudstones II, J. Schieber, W. Zimmerle, and P. Sethi, (Eds.), (pp. 255-282). Stuttgart, E. Schweizerbart'sche Verlagsbuchhandlung.

26. Lewan, M. D. (1984). Factors controlling the proportionality of vanadium to nickel in crude oils. Geochim. Cosmochim. Acta. v. 48, p. $2231-2238$.

27. Murat, RC. (1972). Stratigraphy and Paleogeography of the Cretaceous and Lower Tertiary in southern Nigeria. In: Dessauvagie, T.F.J., and Whiteman A.J. (cd.). African Geology University of Ibadan Press, pp. 251 - 266.

28. Murray, J. W. (1968). Living foraminifers from lagoons and estuaries: Micropaleontology, v. 14, no. 4, p. 435- 455.

29. Murray, J. W. (1991). Ecology and paleoecology of benthic foraminifera. Harlow, Longman Scientific \& Technical, p. 397.

30. Nordeng, S. H. (2012). Basic geochemical evaluation of unconventional resource plays North Dakota. Geological survey Report of investigation No.110, 76p.

31. Nwajide, C. S. (1979). A Lithostratigraphy analysis of the Nanka Sands, southeastern Nigeria. Journal of Mining and Geology. v. 16, 103-109.

32. Obaje, N. G., Wehner, H., Scheeder, G., Abubakar, M. B., \& Jauro, A. (2004). Hydrocarbon prospectivity of Nigeria's inland basins: From the viewpoint of organic geochemistry and organic petrology. AAPG Bull, v. 88, no. 3, p.325- 353.

33. Obi, G. C., Okogbue, C. O., \& Nwajide, C. S. (2001). Evolution of the Enugu Cuesta: A tectonically driven erosional process. Global Journal of Pure Applied Sciences 7, 321-330.

34. Olade, M. A. (1975). Evolution of Nigeria's Benue Trough, a tectonic model. Geological Magazine, vol.112, p.575-583.

35. Peters, K. E. \& Moldowan, J. M. (1993). The Biomarker Guide: Interpreting Molecular Fossils in Petroleum and Ancient Sediments. Englewood Cliffs, N.J., Prentice Hall, p. 363.

36. Petters, K.E. \& Cassa, M. R. (1994). Applied source rock geochemistry. In magoon, L.B., and Dow. W.G. eds. The petroleum system from source to trap. AAPG Memoir 60.Pp.93 - 117

37. Reyment, R. A. (1965). Stratigraphy of some boreholes in the Western Region of Nigeria. Journal of the Nigerian Mining, Geological and Metallurgical Society, v. 2, no. 1, p.1-11. 
38. Schieber, J. \& Zimmerle, W. (1998). Introduction and overview; the history and promise of shale research. In Shales and Mudstones I, J. Schieber, W. Zimmerle, \& P. S. Sethi (Eds.), (pp. 1-10). E. Schweizerbart'sche Verlagsbuchhandlung Naegele u. Obermiller Stuttgart, Germany.

39. Short, K. C. \& Stauble, A. J. (1967). Outline of Geology of Niger Delta. Bulletin of American Association of Petroleum Geologist v. 51, p. 761-779.

40. Simpson, A. (1954). The Geology of Parts of Onitsha, Owerri, Benue Provinces and the Nigerian Coal field. Geol. Surv. Nigeria Bull., v. 24, p. 1-140.

41. Tissot, B., Durand, J., Espitalie, \& Combaz, A. (1974). Influence of the nature and diagenesis of organic matter in the formation of petroleum: AAPG Bulletin, v. 58, p. $499-506$.

42. Tissot, B. P. \& Welte, D. H. (1984). Petroleum Formation and Occurrence, 2nd ed. Springer Verlag, Berlin p. 699.

43. Vine, J. D. \& Tourtelot, E. B. (1970). Geochemistry of black shale deposits- a summary report. Econ. Geol. Vol.65, p253-272.191.

44. White, E. I. (1926). Eocene fishes from Nigeria. Geol. Surv. Nigeria Bull, 10, 82 p. 